\title{
Refugees of Conflict, Casualties of Conjecture: The Trojan Horse Theory of Terrorism and its Implications for Asylum.
}

\author{
Cory Eybergen \\ School of Criminology, Simon Fraser University, 8888 University Drive, Burnaby BC V5A 1S6, \\ Canada, phone: 778-782-3213, fax: 778-782-4140, email: cory_eybergen@sfu.ca \\ Martin A. Andresen \\ School of Criminology, Simon Fraser University, 8888 University Drive, Burnaby BC V5A 1S6, \\ Canada, phone: 778-782-7628, fax: 778-782-4140, email: andresen@sfu.ca
}




\title{
Refugees of Conflict, Casualties of Conjecture: The Trojan Horse Theory of Terrorism and its Implications for Asylum.
}

\author{
There are more displaced persons worldwide today than there ever has been before. Many \\ countries, despite the urgent need for collective effort in providing for these persons, have been \\ slow to accommodate them. Applicants continue to face stringent legal and practical barriers to \\ asylum, even in countries party to the various international refugee agreements. Restrictions on \\ applications are routinely justified with reference to national security, and in particular to defense \\ against terrorism. There is a belief in some sectors of the polity and public that allowing greater \\ numbers of refugees into the country will result in more incidences of violent terrorism. Refugee \\ resettlement programs are caricatured as the Trojan horse permitting terrorists' passage through \\ national borders. Little has been done, empirically, that could testify to the veracity of such a \\ theory, and that which has been done has been equivocal. Moreover, previous studies were unable \\ to establish anything past a coincidental association between refugee populations and experiences \\ of terrorism. This study explicitly tests the idea that refugees, by their own actions, cause \\ terrorism. The findings of the study do not support Trojan horse or other theories that villainize \\ refugees, nor are they decisive of a connection between refugees and terrorism.
}

Keywords: terrorism; refugees, displaced persons; count regression

\section{Introduction}

Globally, by the end of 2017, there were more than 70 million displaced persons, surpassing record high numbers for the fifth year in a row. ${ }^{1}$ Moreover, 85 percent of the global refugee population are in asylum within developing countries even though developed countries have 60 percent of the world's wealth, with only 3 of the top 20 host countries being developed countries. ${ }^{2}$ When this is considered as a function of GDP per capita, none of the top twenty refugee hosting nations are classified as developed, nor are there any in the top thirty, and only one (Germany) makes it into the top forty, at $40^{\text {th }}$ place. 
Based on these data, it should come as no surprise that the democratic nations of the West that claim to have respect for international law, a commitment to basic human rights, and principles of asylum are contradicted through their often formidable legal and practical barriers placed between aspiring asylum seekers and successful applications. ${ }^{3}$ Attempts to reconcile this discordance are usually made with reference to national security and defence against terrorism. The September 11 attacks were pivotal in forcing a reappraisal of national security systems and immigration policies, with implications not only for voluntary migrants, but refugees as well. After the attacks, any solidarity with the international agreements meant to govern state conduct toward refugees gave way to a cynical, "realist" approach to policy making, where the selfinterest of the state - now couched in language related to anti-terrorism - assumed precedence. ${ }^{4}$

In those early years, restrictions on the movement of refugees were more a collateral effect of tightening migration policies than they were a focused security response: of the nineteen men implicated in the September 11 attacks, none were refugees, so there was little cause to draw a connection between refugee resettlement and terrorism exposure. ${ }^{5}$ Still, that particular subtlety did not prevent asylum, as a unique category of migration, from being swept up in the broader trend toward securitization, nor did it prevent the resurrecting of provisions within the United Nations refugee treaties that condoned, in exceptional circumstances, the withholding of refugee status to persons guilty of serious crimes committed elsewhere. Those "exclusionary criteria" provided governments with leverage to deny entry to asylum applicants with even remote, and sometimes dubious, connections to terrorism; persons that they, as signatories to the UN treaties, were otherwise obliged to accommodate. ${ }^{6}$

This same practise continues, but now refugees occupy a distinctive place in the public and political imagination: of the ten countries featured in a survey on European attitudes toward 
minorities, diversity, and national identity, the majority public in eight of them believed that refugees would increase the likelihood of terrorism in their country. ${ }^{7}$ The survey also found that those who had an unfavorable view of Muslims (the majority of people in half of the sampled countries) were also the ones most concerned about the terrorist threat refugees might pose, making clearer another feature of the present century: that the contemporary preoccupation with "terrorism" is in fact a preoccupation with a particular (Islamic) terrorism.

The trepidation inspired by the recent refugee crisis cannot be explained solely with reference to its scale when many of the same countries were met with a comparable or greater number of asylum seekers in the early 1990s and handled them then without the sense of foreboding so customary now. ${ }^{8}$ At minimum, the origins of the displaced persons (predominantly Muslim countries in the Middle East and Africa) during an era defined by the fear of jihadist terrorism plays a role. The conflicts in Iraq and Syria forced from their homes people who then fled north to Turkey and into Europe; as they did, countries within EU borders experienced terrorist attacks, the worst of which ISIS claimed responsibility for, while simultaneously claiming that approximately 4,000 of its own members had entered Europe under cover of the refugee wave. ${ }^{9}$ This time, unlike the September 11 attacks, asylum seekers could be traced anecdotally and sometimes directly to a few of the most serious instances of jihadist terrorism, with the result that refugees were equated with terrorists and resettlement programs were caricatured as the 'Trojan horse' permitting Muslim terrorists' invasion of the West. ${ }^{10}$

The counter argument that these are exceptionally rare events, and that the majority of jihadist attacks on European soil have come from individuals born in Europe, where Muslims are routinely of the underclass, living in segregated neighborhoods, "facing discrimination in employment, harassment by police, and an uncertain future", has so far proven less compelling. ${ }^{11}$ 
Instead, Trojan horse narratives continue to receive endorsement, leading to a shrinking number of successful refugee applications even while the global refugee population rises. ${ }^{12}$ Despite its virulence, the implications of its message for the real, tangible likelihood that aspiring applicants will be cleared for resettlement, little evidence has been presented that could clarify the veracity of Trojan horse or likeminded refugee-as-terrorist conjectures. This study hopes to build on the work of those who offered the first attempts at this problem, to extend its analysis to more recent years (2008-2016), and to interrogate more explicitly the idea that refugees, by their own actions, threaten national securities.

\section{Refugees and terrorism}

Few studies have explored the supposed relationship between refugees and terrorism, with mixed results. The first research studies in this area found evidence that refugee populations were an important element in explaining the frequency of terrorist attacks in host countries. ${ }^{13}$ Choi and Salehyan, in particular, found that countries with larger refugee populations also experienced a greater number of and magnitude of (number of casualties) terrorist attacks. Randahl, ${ }^{14}$ on the other hand, found no statistically significant association between the number of refugees hosted and the incidence, or the magnitude, of terrorist attacks. Given the exposure that both refugees and terrorism share in today's world politics the desire to achieve as close as possible an account of the relationship contemporarily is a primary task of this study.

\section{The demographics of terrorism and its implications for the Trojan horse theory}


There are several explanations for why hosting greater numbers of refugees might provoke greater terrorist activity within destination countries. Most of these would fall under one of two general categories, which might be called "Refugee as Victim" and "Refugee as Villain". With respect to the former, refugees could inspire a greater frequency of terrorist attacks in their capacity as the victims of, or the motivation for, those attacks, whether as the victims of crossborder raids on refugee camps ${ }^{15}$ or of right-wing or other nativist groups who target them based on ethnic, cultural, or religious differences, or as the pretext for those groups to target elements of the public or state. ${ }^{16}$ In any case, the rise in the number of terrorist attacks is a consequence of action taken against, or on account of, refugees rather than that taken by them.

Explanations falling under the Refugee as Villain category, synonymous with the idea of refugees as the Trojan horse of terrorism, have achieved far more currency in contemporary world politics. The unifying premise is that terrorism is by the refugees themselves, based on radicalization that happened before or after arrival at the destination country. Familiar to popular political and public culture is the idea of the individual who, already radicalized and with ill intent, under the guise of refugee slips into the host country and strikes from within. Less familiar is the idea of the individual whose radicalization happens after the fact, resulting from deficiencies in refugee welfare after their arrival. ${ }^{17}$ If refugees should experience poverty not only in its material but symbolic - stigma, shame, powerlessness - dimensions, ${ }^{18}$ then such a population, desperate and starved for security and purpose, might make easy recruits for armed factions that promise relief for themselves and their families. In either case - pre- or post-arrival radicalization - the presumption is that a larger pool of potential terrorists would necessarily prompt a greater frequency of terrorist attacks. 
The distinction between terrorism as action by, versus reaction to, refugees is an important one, but one that previous studies were ill-equipped to evaluate. Refugee populations in those studies were always in aggregate, never considered for their demographics, with the result that the authors were circumscribed in their ability to determine if the apparently refugeerelated terrorism counts they observed were product of that done by, or done on account of, the refugees. There is good reason to care about refugee demographics, particularly as it relates to terrorism, because notwithstanding what may be, in recent years, growing involvement by female individuals in terrorist activity, or the possibility that their participation might have always been greater than that typically credited them (but simply practised in ways less visible than their male counterparts), still there remains wide recognition that terrorism, like crime generally, is performed disproportionately by young males. ${ }^{19}$ Somewhat unlike crime, for terrorism "young" has more fluid meaning: violent terrorism offenders are typically older than violent criminals, they fall, on average, within a broader age range (18-32), and it is not particularly unusual to find some in their late thirties or early forties. ${ }^{20}$

If it is the case that acts of terrorism are performed by males of a particular age range, then this is an important factor in understanding causality. If Trojan horse theories are true, then countries most at risk of terrorist attacks should be those whose refugee populations have the largest proportions of young males, theoretically the group most at risk of terrorist involvement. To isolate this category of the population is only to provide an impression of the typical, and not to imply, in its genuine absence, an immutable terrorist profile, ${ }^{21}$ which the accounts of female terrorists would invalidate anyway. As guilty as over generalization it might be, it might also provide the most fertile ground for launching at least some kind of inquiry into the veracity of the refugee-terrorist conjecture. 


\section{The economic argument}

There is a belief that refugee populations might, by their arrival in large number, upset national economies. $^{22}$ Negative impacts on the economies of destination countries through job and social benefit loss may be brought on by large groups of refugees entering local or national labor and consumer markets. ${ }^{23}$ In Turkey, however, the arrival of Syrian refugees has been shown to have had a negligible effect on wages, ${ }^{24}$ and a beneficial effect on consumer prices for goods and services $^{25}$ — see Esen and Binatl for an opposing result. ${ }^{26}$ Fakih and Ibrahim found that Syrian refugees had had no significant effect on the labour market in neighboring Jordan, ${ }^{27}$ while Baloch et al. found that Afghan refugees, over the course of thirty-five years, had had a significant, negative impact on the Pakistani economy in both the short and long run. ${ }^{28}$ Others found that refugee camps might have significant spillover effects on host economies, with local incomes benefitting from the market interactions between the refugees and ambient businesses, as the Congolese camps in Rwanda demonstrated. ${ }^{29}$

Together these studies offer little consensus on the economic impact of refugees, and even less can be argued of the real effect that these more or less serious disruptions of economy have had on terrorism in each country. Part of the difficulty is in reconciling short term setbacks

(unemployment and reduced wages) with long term improvements (increases in social capital). ${ }^{30}$ Still, the immediate effects might have importance for terrorism: terrorism might be the equally immediate response by affected native groups to the immediate practical-material consequences of a waning economy. The decision to include a series of economy variables in the analyses to come is, therefore, made in cognizance of that possibility. 


\section{Data and methodology}

This study uses panel data from 70 countries, 2008 to 2016. The unit of analysis is country-year, for a total of 630 cases. The selection of both the timeframe and countries were, in either case, affected by the availability of data for key variables in the study. Figure 1 maps the countries featured in the study. Notwithstanding a scarcity of European representation - an unfortunate, though unavoidable, reality of available refugee demographics data - Figure 1 shows that these 70 countries are fairly well distributed with no regions left without one or two national representatives.

\section{Defining and measuring terrorism}

Consistent with previous research, we evaluate the impact of refugee populations on the frequency and magnitude of terrorist attacks, available from the Global Terrorism Database (GTD), an open source data set providing systematic information on terrorist incidents, globally, from 1970 to $2017 .{ }^{31}$ Consistent with GTD definitions, we define terrorism as an intentional, violent attack committed by a non-state actor that, simultaneously, meets at least two of the following three criteria: the act is "aimed at attaining a political, economic, religious, or social goal"; there is an intention to "coerce, intimidate, or convey some other message to a larger audience"; and the action is "outside the context of legitimate warfare activities". ${ }^{32}$

Two models are specified, both utilizing a similar combination of independent variables. The outcome variables, frequency and magnitude of terrorist attacks, are counts. The first model will explore the frequency of terrorist attacks, measured as the total number of attacks in each 
country for each year between 2008 and 2016. The second model will explore the magnitude of terrorist attacks for those same country-years, with magnitude measured as the total number of casualties (killed and wounded) in those attacks. The descriptive statistics and correlations for the terrorism variables and the independent variables are presented in Tables 1 and 2, respectively.

$<$ Insert Figure 1 About Here $>$

\section{Defining and measuring "persons of concern", and the demographics of such persons}

In the current study, we use the broad definition used by the UN for those designated "persons of concern": a proxy term for the large group of displaced persons worldwide, of which some are true refugees (in that they meet the criteria of the relevant Geneva treaties and have been granted asylum) while others are still seeking asylum or have not yet crossed international borders but have been, nevertheless, removed from home or place of residence. ${ }^{33} \mathrm{We}$ follow this definition because the UN are the provider of demographics information for displaced persons and these data are not disaggregated by subgroup (refugees vs. IDPs vs. asylum seekers, etc.).

\section{$<$ Insert Table 1 About Here $>$}

We use two variables to evaluate the effect of displaced persons populations on terrorist attacks. The first is a simple count variable of the total number of displaced persons residing in each country for each year, intended to measure, as previous studies had, whether the absolute number of such persons hosted by a country have an impact on its likelihood of experiencing terrorism. To account for the positive skew in the data and to ease interpretations, the natural logarithm of each value is used. 
The second variable measures the proportion of the overall displaced persons population that is young and male, the group theoretically most at risk of terrorist involvement and associated with the Trojan horse explanations. Demographic information on displaced persons populations are obtained through the $\mathrm{UN}$ as well. Data are disaggregated into age ranges for female and male persons, showing the total number of individuals in each category residing in a particular country during a particular year, allowing for calculation of the proportion of the overall population within each category. The age categories themselves, as defined by the UN, are limited: 0 to 4,5 to 11,12 to 17,18 to 59 , and 60 or older. From these, the category 18 to 59 is the best approximate of young male; though not ideal, this is the best approximation available and is not far out of line from the broader age range and advanced maturity of the typical terrorist.

\section{Structural correlates of terrorism}

Several other factors must necessarily be included in the analysis to ensure that any results found for the refugee variables are the product of their unique effect on terrorism and not simply an artifact of omitted variable bias. Choi and Salehyan and Randahl identified the important, nationlevel controls. These are: total population, economic development, regime type, domestic and neighboring conflict, and previous terrorism. Population and economic development data were gathered from the World Bank, through its open data portal. ${ }^{34}$ Because more populous countries can probably expect, simply by scale, more terrorists and terrorist attacks, and because the economic well-being of a country might predict its susceptibility to terrorism, variables 
measuring national population and GDP per capita (a measurement of economic development) were included, both logged to remedy the positive skew in the data and to ease interpretations.

There is ambivalence about the role political systems play in encouraging or suppressing terrorism: whether or not democracies, versus autocracies, are better equipped to handle grievances institutionally or, rather, if expanded freedoms allow for a broader scope of, potentially violent, action. A polity variable is constructed using the Polity IV Project data set, which assigns to countries, each year, scores on a scale from - 10 for the most autocratic nations to 10 for the most democratic. ${ }^{35}$ To account for the possibility that the relationship between regime type and terrorism is quadratic - terrorism highest for countries with no identifiable political system or a weak imitation of one of them (a common property of countries in conflict) - a squared term is included in the analyses.

The next two variables measure the level of conflict in the host nation itself as well as that in the countries contiguous to it, controlling for the effect of internal instability and war on terrorism and the "spill-over" effects of likewise conflict in neighboring countries, respectively. Data for both come from the Major Episodes of Political Violence data set, which awards an overall magnitude of political violence score to each country, for each year, based on its combined levels of intra and interstate armed conflict, and ranges from 0 to 70 , with increases indicating greater levels of conflict. ${ }^{36}$ However, because few countries had values on this measure for the years in the study, a binary variable was created that separated those with no score on armed conflict from those with any score greater than zero. The neighbor conflict score was calculated manually, by taking the conflict score of each country contiguous to the focal country, for each year, and averaging their values. A higher score here should indicate a greater level of conflict in areas immediately adjacent to the focal country and, perhaps, an attendant 
vulnerability in that country to spill-over violence from its neighbors. The values for this measure ranged, in this study, from 0 to a maximum of 9 , with many more countries scoring greater than zero on this measure, for more years, than had been the case for the companion score on domestic conflict. This so, the neighbor conflict variable was not similarly dichotomized, but left as a numeric value from 0 to 9 .

We also include a measure of the political rights enjoyed by a nation's citizenry, an indicator of its relative freedom. These data come from the Freedom in the World indices of political rights and civil liberties data set provided by Freedom House.${ }^{37}$ Countries are scored from 1 to 7 on the extent that their citizenries are afforded political rights, with 1 indicating the most political rights (freedom) and 7 the least or most restricted. Abadie, in 2006, found that political freedom was not, as might be expected, linearly related to terrorism (with greater freedom predicting lesser terrorism) but was, instead, quadratic, with terrorist activity highest for countries of intermediate freedom, decreasing as one moved toward the poles representing the most freedom and the least. ${ }^{38}$ Thus, to account for the possibility of similar nonlinearity in the data of this study, a squared term is included in the analyses. Finally, a variable measuring extrajudicial violence perpetrated by agents of the state is included in the analyses, based on previous research that found a connection between cultures of violence - based on general levels of legitimate and illegitimate violence - and experiences of terrorism: the more violence-prone countries experiencing an attendant greater vulnerability to terrorist violence. ${ }^{39}$ The Political Terror Scale (PTS), provided by Gibney et al., ${ }^{40}$ awards countries a score from 1 to 5 based on the extent to which the basic human rights and physical integrity of persons are violated by agents of the state ${ }^{41}$ with 1 indicating countries with the least state "terror" and 5 indicating those with the most. These data were incorporated into the study. 
Lastly, each nation-level predictor is lagged one year behind the outcome variable to ensure the direction of causality and to ward against possible circular effects of terrorism causing conflict, displaced persons populations, political terror, etc., instead of the other way around. ${ }^{42}$ We also use a lagged dependent variable as a predictor variable to account for the effect that a history of terrorism has on its likelihood of continuity in a given country. ${ }^{43}$

\author{
$<$ Insert Table 2 About Here $>$
}




\section{Measures of the economy}

In addition to GDP per capita, three auxiliary measures of the economy are included in the analyses: unemployment, consumer prices, and income. Unemployment is measured as the percentage of the labor force unemployed, inflation is used as a measure of consumer prices, and income is measured as the gross domestic product per person adjusted for differences in purchasing power; data for each of these was gathered from the World Bank. Because the goal is to assess whether a "shock" to the economy brought on by an expanding displaced persons population results in greater terrorist intensity, rather than simply using the value of each measure for each year we use instead the percent change in that measure's value from that of the previous year. If the interest is in the change to the economy that displaced persons might bring about, then what matters is not the absolute value of the measure but how it has changed over the years as these populations themselves grew or shrunk and, subsequently, how those greater or lesser changes in economy impacted the incidence and magnitude of terrorism. That being so, these variables are calculated as the percent change from the previous year.

\section{Estimation}

This study uses panel data from 70 countries over a period of nine years. The dependent variables, terrorism frequency and magnitude, are counts. The appropriate estimation technique for these data are, therefore, count regression models with consideration for the possibility of fixed or random effects in the data. The data were initially pooled, then fitted with a random effects model and a fixed effects model. The models were then tested against each other in order 
to determine which was appropriate for the data. The Lagrange Multiplier test suggested that the fixed effects model is preferred to the pooled model and, similarly, the Hausman test for fixed versus random effects suggested that fixed effects are more appropriate for these data. Therefore, the subsequent models included, along with the other regressors, variables for the fixed effects.

A similar iterative process was used to select the appropriate count regression estimator. The data were initially modeled using Poisson as the estimation technique and then tested for possible overdispersion. The test indicated that the data were overdispersed, so a negative binomial model is used. The negative binomial models were tested for heteroscedasticity, autocorrelation, and multicollinearity. Tests for multicollinearity were performed without the fixed effects variables and without the squared terms of the polity and political freedoms variables which could be expected to show high collinearity with their bases. The variance inflation factors for each of the independent variables were, for both models, below 5.0, suggesting that multicollinearity was not an issue. The Breutsch-Pagan test for heteroscedasticity and the Durbin-Watson test for autocorrelation were, however, both significant, providing an indication of the presence of both in the data. In order to remedy the possible issues of heteroscedasticity and autocorrelation, each model was corrected using White robust standard errors.

Finally, because terrorism data may involve an excessive number of zero observations the argument could be made that this data should be modelled accordingly, using a zero-inflated negative binomial model. When considering the number of terrorist incidents, 286 of 630 cases are non-events, and of 70 countries 9 are of the "always zero" category (in that they never, in any of years sampled, experienced an incident of terrorism), and when considering the number of casualties from terrorist incidents, 342 of 630 cases are non-events, and 12 countries are of the 
always zero category. While this does not necessarily represent an excess of zeros (just under 50 percent and just over 50 percent, respectively), the number might be sizeable enough that an argument could be made that a separate process might be responsible for generating more than

the expected number of zeros, typically the justification for inflated models. ${ }^{44}$ Thus, zero-inflated models, corrected again with White robust standard errors, were specified for both outcome variables and compared against standard negative binomial models on both their Akaike information criterion (AIC) and Bayesian information criterion (BIC). ${ }^{45}$ The Vuong test was used in order to determine, statistically, which approach was to be preferred. These tests suggested that when the outcome is the number of terrorist attacks, a standard negative binomial model is preferred to an inflated model, but when the outcome is the number of casualties from those attacks, for which there are a larger number of non-events, an inflated model is more appropriate.

Ultimately, the effect of each of the displaced persons variables on both outcome variables are the same, qualitatively, no matter the method used, and the only differences in the inflated versus non-inflated models come from minor changes in significance to some of the nation-level controls. Because of this we use the zero-inflated negative binomial regressions on both outcome variables. Results from the standard negative binomial regression are included for reference in Appendix I.

\section{Results}

The results of the zero-inflated negative binomial regression models are shown in Table 3. Of immediate note is that for neither terrorism outcome, frequency or magnitude, was the measure 
for the proportion displaced persons that are young male statistically significant. This finding is complimented, in model one, by the finding of non-significance in the variable measuring the absolute number of displaced persons residing in each country. The size of displaced persons populations was, however, significantly and positively associated with the magnitude of terrorist attacks. In this case, a ten percent increase in the number of displaced persons was associated, on average, with a 1.8 percent $\left(\exp ^{0.185(\ln 1.1)}=1.018\right)$ increase in the expected rate of casualties from terrorist attacks $(\mathrm{p}<0.1)$. Interpreted together, the displaced persons variables suggest the following. When terrorism is evaluated on the frequency of its occurrence, neither are the size of displaced persons populations nor the proportion of those populations who are young male related to the number of terrorist attacks experienced by the host country. When terrorism is evaluated on the magnitude of its impact, the sum of persons killed and wounded in terrorist attacks, the size of displaced persons populations appears to matter, but the proportion of those populations who are young male does not. If the Trojan horse and likeminded Refugee as Villain hypotheses are not to be rejected, then the proportion of the at-risk group of displaced persons should be related to the magnitude of terrorist attacks suffered by host countries, with greater proportions of young males tied to greater magnitudes of terrorism. That the two are not related suggests that the number of casualties from terrorist attacks is attributable, perhaps, not to the actions of refugees themselves, but to actions taken against, or on account of, them.

\section{$<$ Insert Table 3 About Here $>$}

Several other findings are worthy of mention. Previous experiences of terrorism were a significant and positive predictor of later terrorism. ${ }^{46}$ With respect to the frequency of terrorist attacks, a ten percent increase in the number of incidents in the previous year corresponded with a 1.9 percent $\left(\exp ^{0.196(\ln 1.1)}=1.018\right)$ increase in the expected rate of terrorist attacks in the 
subsequent year $(\mathrm{p}<0.001)$. Similarly, with respect to the magnitude of terrorist attacks, and on the zero side of the model, a ten percent increase in the number of casualties in the previous year decreased the likelihood that a country would never suffer casualties from terrorist attacks by 5.1 percent $\left(1-\exp ^{-0.545(\ln 1.1)}=0.051\right)(\mathrm{p}<0.001)$.

The population of a country was a significant predictor of its vulnerability to both the frequency of terrorist attacks and the magnitude of those attacks. A ten percent increase in population was associated with a 57 percent increase in the expected rate of terrorist attacks $(p<0.05)$ and a 123 percent increase in the expected rate of casualties from those attacks $(\mathrm{p}<0.01)$. A higher level of economic development in a country, measured here by GDP per capita, seems to insulate countries from terrorist attacks: in this case, a ten percent increase in GDP per capita was associated with an 11.7 percent decrease in the expected rate of terrorist incidents $(\mathrm{p}<0.01)$.

The results for the polity variable seem to support the idea that it is not very autocratic or very democratic countries that attract the most terrorism, but countries in between political systems or those with a weak imitation of one of them. With respect to the frequency of terrorist attacks, both the squared polity variable and its base are significant but with opposite signs, suggesting that more democratic countries experience more terrorism only until a certain point, whereupon being more democratic begins to lessen the likelihood of high counts of terrorism. When this is considered in terms of terrorism magnitude, a different relationship emerges: here, countries that are more democratic suffer, exponentially, fewer casualties. Similarly, and in support of the argument made by Abadie, ${ }^{47}$ the level of political freedom in a country, too, forms a curvilinear relationship with the magnitude of terrorist attacks. Both the squared restrictions on political freedom variable and its base are significant but with opposite signs, indicating that 
countries with greater restrictions on political freedom will suffer fewer casualties from terrorist attacks, but only until a certain point, whereupon greater restrictions begin to increase the likelihood of greater casualties from terrorist attacks. For both terrorism frequency and magnitude, domestic conflict emerges as an important, and positive, predictor; interestingly, neighbor conflict, and the possibility of spill-over violence that it implies, is not a statistically significant predictor of terrorism in either of its dimensions. The results for the state violence variable indicates that as the degree of state violence increases, so too will the expected rate of terrorist attacks $(\mathrm{p}<0.1)$; interestingly, a higher degree of state violence is also associated with a greater likelihood that a country will never experience terrorist attacks $(\mathrm{p}<0.05)$, indicating, perhaps, that repressive action performed by government actors can be either very effective at controlling native populations or, conversely, motivation for its revolt.

A final consideration, and of importance for our research questions, are the measures of changes to the economy included to test the possibility of an indirect relationship between displaced persons populations and terrorism. There is little to report here: of the three variables, only percent change in income had a statistically significant association with terrorism, and this only for the magnitude of terrorist attacks. A one percent increase in income corresponded with a 2.8 percent $\left(1-\exp ^{-0.028}=0.028\right)$ decrease in the expected rate of casualties from terrorist attacks $(p<0.1)$; and, on the zero side of the model, a one percent increase in income increased the likelihood that a country would not suffer casualties by 11 percent $\left(\exp ^{0.102}=1.107\right)(p<0.1)$.

Clearly, changes in average income are important for understanding at least one of the dimensions of terrorism. If displaced persons populations are to predict lesser or negative changes in income, then there might be support, albeit thin support, for the idea that the relationship between displaced persons and terrorism is indirect, the product of negative 
disruptions to national economies brought on by refugee populations and resisted by affected native groups. In order to test for this, a linear regression model was specified with percent change in income as the outcome, and the same was done for GDP per capita (which was a statistically significant predictor of the frequency of terrorism). In neither case was either of the displaced persons variables statistically important as predictors of changes in income or GDP per capita, indicating that while these indicators of economy might be statistically related to different dimensions of terrorism, displaced persons populations are not statistically related to them, thereby offering little support for the argument of an indirect relationship between these populations and terrorism intensities. Together then with the results of the displaced persons variables, the overall picture is one that should seem to refute wholesale delegation of responsibility to displaced persons for the experiences of terrorism that destination countries on occasion endure.

\section{Discussion and conclusion}

The results from this study offer important information that might, nonetheless, be recognized for its banality were they received by a culture firmly resolved in its commitment to universal human rights and dignity. For such a culture, the finding that refugees should not be found culpable of violent acts of terror would be regarded a truism: that, barring exceptional deviations from the rule, refugees who are mostly looking only to escape conflict or repression might be, consequently, of the least likely of persons to engage violently with the country that receive them. That the practise of asylum should instead, today, be greeted with resentment and fear betrays not just a basic misapprehension of the persons guilty of violent terrorism but a failure of 
the overall project of liberalism and its universalizing morality of equality of treatment and dignity. ${ }^{48}$

The rebound since World War Two of nationalism in Europe and the West is certainly troubling for the fear and resentment it was founded on, but more worrisome should be the populist claim that its hold on Western nations reflect the true feelings of the democratic majority. ${ }^{49}$ Lost in the clamor for tighter migration policies, and neglected even by those whose pity or sense of generosity moves them to welcome the dispossessed, are the international agreements that, in ostensibly legal form, demand recognition of the most basic human rights; the acknowledgement of which were the entire reason for the creation of the international institutions whose moralizing intentions are, unfortunately, complimented by a practical impotence to enforce the values they represent. ${ }^{50}$

The refugee conventions, in abstraction legally binding, are, in practise, subordinate to the prerogatives of the countries signed to them. Thus, in the U.S. and in Sweden (cases in point though hardly unique, in this regard, among nations of the West), when issues of refugee status come up in jurisprudence only perfunctory attention is given to the recommendations of international monitoring bodies; the judiciary, in the last analysis, deferring to the state's own, or regional, statutes. Such was the case when the American judiciary, with recourse not to refugee law but to U.S. constitutional provisions, fought Trump's January 2017 attempt to suspend all refugee admissions to the U.S. and ban entrance to all other citizens from seven predominantly Muslim countries, ${ }^{51}$ and when, in 2012, the Swedish judiciary convened to determine the status of a female applicant from the Democratic Republic of the Congo, shrugging off the counsel of the UN committee who steadfastly defended her right to asylum, given the risk of her being subjected to sexual violence if forcibly returned to the DRC. ${ }^{52}$ 
That the attention to international law should be so superficial among governments and their public must provide the source, more than anything else, for the most discouragement among human rights advocates, who, rather than in the isolated pockets of pitying or charitable members of the public, see the solution to the insularity of national populisms in a bona fide, cultural revival of the belief in the basic human rights and solidarity of all people. ${ }^{53}$ The barriers to migration that exist today (the scaffolding of which were the immediate response to September 11) present one of the greatest obstacles to the resurrection of the post-World War Two solidarities that formed, fundamentally, from an appreciation - learned at great cost - of the need for communal checks on freewheeling nationalism.

Presently, terrorism serves as the pretext for much of the apparatus that restricts the movement of migrants forced or otherwise. In the context of forced migration, terrorism often provides the justification for the refusing of asylum to individuals that national governments - at least those party to the Geneva refugee agreements - are otherwise, nominally, obliged to accommodate. Its roots in the events of and following September 11, the belief that refugee populations are somehow associated with violent terrorism - that each refugee is a potential terrorist and that refugee resettlement programs are the Trojan horse permitting Muslim terrorists' invasion of the West - has since degenerated to the point that its message is received by sizeable parts of the public and polity with little objection or censure. The present study was intended, explicitly, to offer evidence on the veracity of that belief. The results here do not support the conclusion that refugee populations are to blame for the scale of terrorism in host countries; in terms of the absolute number of terrorist attacks, the two are not even related. It seems, thus far, that the accounts of individual refugees or asylees engaging in acts of terrorism have wildly eclipsed the unspoken accounts of the resounding majority that look only in their 
new country for an opportunity for peace and security. There have been few attempts to demonstrate empirically the truth of that fact, despite the very real consequences its misapprehension has for very real people in need of safety and solicitude. 


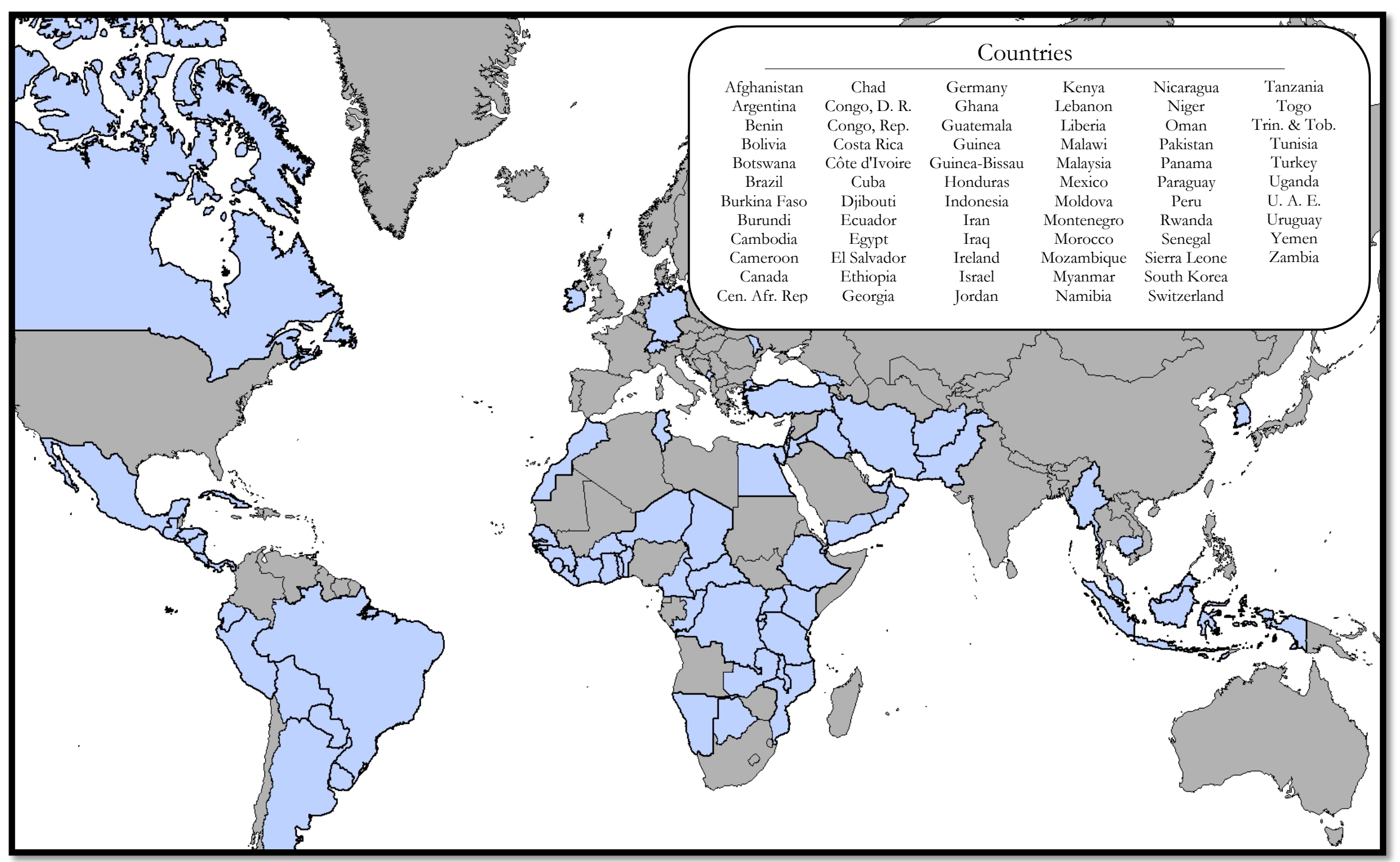

Figure 1. Map of sampled countries. Light blue indicates countries featured in the study (i.e., those with demographic information for their displaced persons populations). 
Table 1. Descriptive Statistics

\begin{tabular}{|c|c|c|c|c|}
\hline & Mean & Standard deviation & Minimum & Maximum \\
\hline Incidents & 69.7 & 311.2 & 0 & 3,369 \\
\hline Casualties & 426.7 & 2168.1 & 0 & 25,059 \\
\hline Incidents $_{\mathrm{t}-1}(\ln )$ & 1.3 & 1.8 & 0 & 8.1 \\
\hline Casualties $_{\mathrm{t}-1}(\ln )$ & 1.8 & 2.5 & 0 & 10.1 \\
\hline Displaced persons $_{\mathrm{t}-1}(\mathrm{ln})$ & 9.9 & 3.0 & 2.7 & 15.4 \\
\hline Proportion young male $_{t-1}$ & 0.37 & 0.18 & 0 & 0.97 \\
\hline Population $_{\mathrm{t}-1}(\ln )$ & 16.4 & 1.3 & 13.3 & 19.4 \\
\hline GDP per capitat-1 (ln) & 7.9 & 1.5 & 5.1 & 11.4 \\
\hline Polityt-1 & 3.9 & 5.3 & -8 & 10 \\
\hline Conflict $_{t-1}$ & 0.18 & 0.39 & 0 & 1 \\
\hline Neighbor conflict ${ }_{t-1}$ & 0.8 & 1.0 & 0 & 9 \\
\hline Political freedom ${ }_{\mathrm{t}-1}$ & 3.8 & 1.9 & 1 & 7 \\
\hline State violence $_{t-1}$ & 2.7 & 1.1 & 1 & 5 \\
\hline Unemployment, $\%$ change & 0.1 & 17.5 & -88.1 & 154.8 \\
\hline Income, $\%$ change & 3.6 & 4.9 & -38.1 & 34.5 \\
\hline Inflation & 6.0 & 6.8 & -35.8 & 61.4 \\
\hline
\end{tabular}

$\mathrm{N}=630$ 
Table 2. Bivariate Correlations

\begin{tabular}{|c|c|c|c|c|c|c|c|c|c|c|c|c|c|c|c|}
\hline & ${ }^{a} \mathrm{X}_{1}$ & $\mathrm{X}_{2}$ & $\mathrm{X}_{3}$ & $\mathrm{X}_{4}$ & $\mathrm{X}_{5}$ & $\mathrm{X}_{6}$ & $\mathrm{X}_{7}$ & $\mathrm{X}_{8}$ & $\mathrm{X}_{9}$ & $\mathrm{X}_{10}$ & $\mathrm{X}_{11}$ & $\mathrm{X}_{12}$ & $\mathrm{X}_{13}$ & $\mathrm{X}_{14}$ & $\mathrm{X}_{15}$ \\
\hline $\mathrm{X}_{1}$ & ---- & & & & & & & & & & & & & & \\
\hline $\mathrm{X}_{2}$ & $0.91 * * *$ & ---- & & & & & & & & & & & & & \\
\hline $\mathrm{X}_{4}$ & $0.73^{* * *}$ & $0.73 * * *$ & $0.90 * * *$ & ---- & & & & & & & & & & & \\
\hline $\mathrm{X}_{5}$ & $0.56^{* * *}$ & $0.55^{* * *}$ & $0.53^{* * *}$ & $0.53^{* * *}$ & ---- & & & & & & & & & & \\
\hline $\mathrm{X}_{6}$ & $-0.19 * * *$ & $-0.29 * * *$ & $-0.17 * * *$ & $-0.27 * * *$ & $-0.60 * * *$ & ---- & & & & & & & & & \\
\hline $\mathrm{X}_{8}$ & -0.04 & $-0.17 * * *$ & -0.04 & $-0.18^{* * *}$ & $-0.23 * * *$ & $0.61 * * *$ & $-0.08^{*}$ & ---- & & & & & & & \\
\hline $\mathrm{X}_{9}$ & $-1.12^{* *}$ & $-0.22^{* * *}$ & $-0.12^{* *}$ & $-0.22^{* * *}$ & $-0.29 * * *$ & $0.48^{* * *}$ & $-0.15^{* * *}$ & $0.41 * * *$ & ---- & & & & & & \\
\hline $\mathrm{X}_{10}$ & $0.59 * * *$ & $0.59 * * *$ & $0.60 * * *$ & $0.62 * * *$ & $0.46^{* * *}$ & $-0.20 * * *$ & $0.35^{* * *}$ & $-0.14 * * *$ & $-0.21 * * *$ & ---- & & & & & \\
\hline $\mathrm{X}_{11}$ & $0.39 * * *$ & $0.42^{* * *}$ & $0.37^{* * *}$ & $0.41^{* * *}$ & $0.54^{* * *}$ & $-0.40^{* * *}$ & $0.25^{* * *}$ & $-0.15^{* * *}$ & $-0.37 * * *$ & $0.34^{* * *}$ & ---- & & & & \\
\hline $\mathrm{X}_{12}$ & $0.19 * * *$ & $0.29 * * *$ & $0.18^{* * *}$ & $0.28^{* * *}$ & $0.31 * * *$ & $-0.51 * * *$ & $0.10^{*}$ & $-0.46^{* * *}$ & $-0.84 * * *$ & $0.27 * * *$ & $0.37 * * *$ & ---- & & & \\
\hline $\mathrm{X}_{13}$ & $0.47 * * *$ & $0.53 * * *$ & $0.48^{* * *}$ & $0.55^{* * *}$ & $0.41 * * *$ & $-0.24 * * *$ & $0.41 * * *$ & $-0.35^{* * *}$ & $-0.44 * * *$ & $0.60 * * *$ & $0.37 * * *$ & $0.51 * * *$ & ---- & & \\
\hline $\mathrm{X}_{14}$ & -0.00 & 0.01 & -0.05 & 0.01 & 0.06 & -0.05 & 0.03 & -0.06 & -0.02 & 0.01 & 0.06 & 0.05 & 0.05 & ---- & \\
\hline $\mathrm{X}_{16}$ & 0.03 & $0.07^{+}$ & 0.01 & $0.08^{*}$ & $0.07^{+}$ & $-0.11 * *$ & $0.15^{* * *}$ & $-0.26 * * *$ & -0.06 & $0.12^{* *}$ & 0.05 & $0.07^{+}$ & $0.23^{* * *}$ & 0.02 & $0.14 * * *$ \\
\hline
\end{tabular}

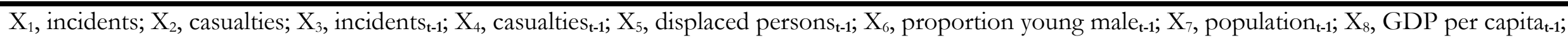

$\mathrm{X}_{9}$, polity $\mathrm{t}_{\mathrm{t}-1} ; \mathrm{X}_{10}$, conflict $\mathrm{t}_{\mathrm{t}-1} ; \mathrm{X}_{11}$, neighbor conflict $\mathrm{t}-1 ; \mathrm{X}_{12}$, restrictions on pol. freedom $\mathrm{t}_{\mathrm{t}-1} ; \mathrm{X}_{13}$, state violence $\mathrm{t}-1 ; \mathrm{X}_{14}$, unemployment $\%$ change;

$\mathrm{X}_{15}$, income $\%$ change; $\mathrm{X}_{16}$, inflation

${ }^{a}$ Note: Spearman's rho used for all bivariate correlations

${ }^{+} p \leq 0.1, * p \leq 0.05, * * p \leq 0.01, * * * p \leq 0.001$ 
Table 3. Zero-Inflated Negative Binomial Regression Results

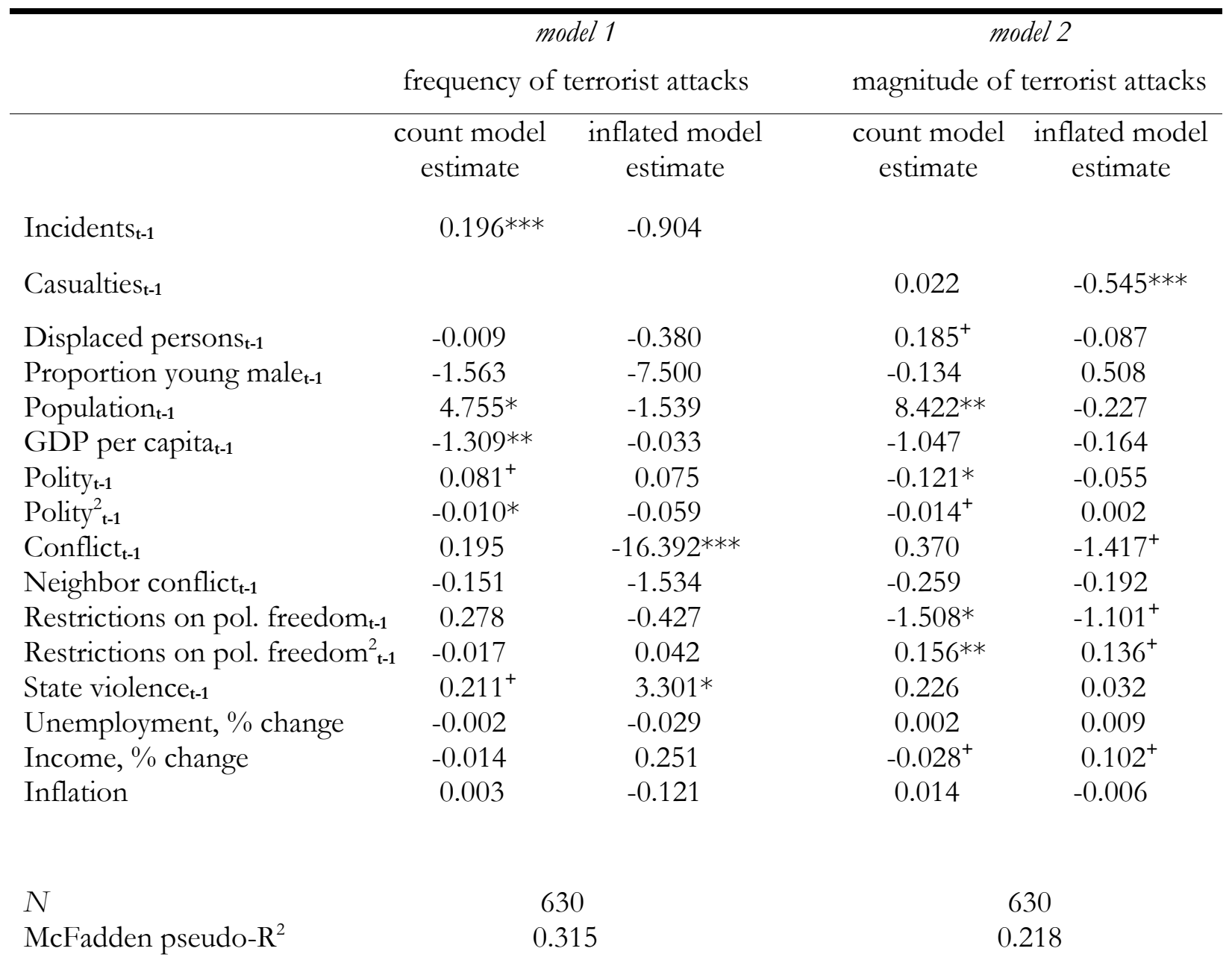

Note: count component includes fixed effects variables (country, year), zero component could not.

${ }^{+} p \leq 0.1, * p \leq 0.05, * * p \leq 0.01,{ }^{* * *} p \leq 0.001$ 
Appendix I

Table A.1. Negative Binomial Regression Results

\begin{tabular}{|c|c|c|c|c|}
\hline & \multicolumn{2}{|c|}{$\begin{array}{c}\text { model } 1 \\
\text { number of terrorist attacks }\end{array}$} & \multicolumn{2}{|c|}{$\begin{array}{c}\text { model } 2 \\
\text { magnitude of terrorist attacks }\end{array}$} \\
\hline & estimate & standard error & estimate & standard error \\
\hline Incidentst-1 $_{\text {Inct }}$ & $0.208^{* *}$ & 0.064 & & \\
\hline Casualties $_{\mathrm{t}-1}$ & & & 0.008 & 0.067 \\
\hline Displaced persons $_{\mathrm{t}-1}$ & 0.014 & 0.078 & $0.222 *$ & 0.092 \\
\hline Proportion young male $_{t-1}$ & -1.426 & 1.576 & -1.358 & 1.132 \\
\hline Population $_{t-1}$ & $5.001 *$ & 2.149 & $7.671 *$ & 3.106 \\
\hline GDP per capitat-1 & $-1.486^{* *}$ & 0.487 & $-1.967 * *$ & 0.669 \\
\hline Polityt-1 & $0.084^{+}$ & 0.044 & $0.136^{+}$ & 0.073 \\
\hline Polity $^{2}-1$ & -0.008 & 0.005 & 0.010 & 0.011 \\
\hline Conflict $_{\mathrm{t}-1}$ & 0.418 & 0.271 & 0.741 & 0.460 \\
\hline Neighbor conflict -1 & -0.142 & 0.114 & $-0.306^{*}$ & 0.137 \\
\hline Political freedom ${ }_{\mathrm{t}-1}$ & 0.341 & 0.334 & 0.046 & 1.343 \\
\hline Political freedom ${ }_{t-1}^{2}$ & -0.025 & 0.035 & 0.005 & 0.124 \\
\hline State violence $_{t-1}$ & 0.100 & 0.109 & $0.401 *$ & 0.166 \\
\hline Unemployment, $\%$ change & -0.000 & 0.002 & 0.004 & 0.004 \\
\hline Income, $\%$ change & $-0.020 *$ & 0.009 & $-0.084 * * *$ & 0.016 \\
\hline Inflation & 0.005 & 0.008 & -0.004 & 0.013 \\
\hline$N$ & & & & \\
\hline McFadden pseudo- $\mathrm{R}^{2}$ & & & & \\
\hline
\end{tabular}

Note: fixed effects variables (country, year) are included.

${ }^{+} p \leq 0.1, * p \leq 0.05, * * p \leq 0.01, * * * p \leq 0.001$ 


\section{Notes}

1“UNHCR Statistics: The World in Numbers," UNHCR, http://popstats.unhcr.org/en/overview (accessed December 10, 2018).

2“'Syria Emergency," last modified April 19, 2018, http://www.unhcr.org/syria-emergency.html (accessed December 10, 2018).

${ }^{3}$ Rebecca Stern, “'Our Refugee Policy is Generous': Reflections on the Importance of a State's Self-Image," Refugee Survey Quarterly 33, no. 1 (2014): 25-43.

${ }^{4}$ Michael Collyer, "Secret Agents: Anarchists, Islamists and Responses to Politically Active Refugees in London,” Ethnic and Racial Studies 28, no. 2 (2005): 279.

${ }^{5}$ Monette Zard, "Exclusion, Terrorism and the Refugee Convention," Forced Migration Review, no. 13 (2002): 32-34.

${ }^{6}$ Melanie Nezer, “The Material Support Problem: Where U.S. Anti-Terrorism Laws, Refugee Protection, and Foreign Policy Collide," The Brown Journal of World Affairs 13, no. 1 (2006): 177-190; Sarah Singer, "Terrorism and Article 1F(c) of the Refugee Convention," Journal of International Criminal Justice 12, no. 5 (2014): 1075-91; Zard, "Exclusion, Terrorism and the Refugee Convention," 32-34.

${ }^{7}$ Richard Wike, Bruce Stokes, and Katie Simmons, "Europeans Fear Wave of Refugees Will Mean More Terrorism, Fewer Jobs: Sharp Ideological Divides Across EU on Views About Minorities, Diversity and National Identity," Pew Research Center (2016): 1-44.

${ }^{8}$ Leo Lucassen, "Peeling an Onion: The 'Refugee Crisis' From a Historical Perspective," Ethnic and Racial Studies 41, no. 3 (2018): 383-410.

${ }^{9}$ Maria do Céu Pinto Arena, "Islamic Terrorism in the West and International Migrations: The 'Far' or 'Near' Enemy Within? What is the Evidence," European University Institute Working Papers RSCAS (2017): 1-29; Marco Funk and Roderick Parkes, "Refugees Versus Terrorists," European Union Institute for Security Studies (2016): 1-2.

${ }^{10}$ do Céu Pinto Arena, “Islamic Terrorism in the West and International Migrations," 1.

${ }^{11}$ Stephen Zunes, "Europe's Refugee Crisis, Terrorism, and Islamophobia," Peace Review: A Journal of Social Justice 29, no. 1 (2017): 2.

${ }^{12}$ Phillip Connor and Jens Manuel Krogstad, "For the First Time, U.S. Resettles Fewer Refugees than the Rest of the World," last modified July 5, 2018, http://www.pewresearch.org/facttank/2018/07/05/for-the-first-time-u-s-resettles-fewer-refugees-than-the-rest-of-the-world/ (accessed January 5, 2019).

${ }^{13}$ Seung-Whan Choi and Idean Salehyan, "No Good Deed Goes Unpunished: Refugees, Humanitarian Aid, and Terrorism," Conflict Management and Peace Science 30, no. 1 (2013): 
53-75; Daniel Milton, Megan Spencer, and Michael Findley, "Radicalism of the Hopeless: Refugee Flows and Transnational Terrorism," International Interactions: Empirical and Theoretical Research in International Relations 39, no. 5 (2013): 621-645.

${ }^{14}$ David Randahl, "Refugees and Terrorism," PAX et BELLUM Journal 3, no. 1 (2016): 46-55.

${ }^{15}$ Milton, Spencer, and Findley, "Radicalism of the Hopeless," 627.

${ }^{16}$ Randahl, "Refugees and Terrorism," 47.

${ }^{17}$ Milton, Spencer, and Findley, "Radicalism of the Hopeless," 623.

${ }^{18}$ Karolina Lukasiewicz, "Exile to Poverty: Policies and Poverty Among Refugees in Poland," International Migration 55, no. 6 (2017): 57.

${ }^{19}$ Gary LaFree and Gary Ackerman, "The Empirical Study of Terrorism: Social and Legal Research," Annual Review of Law and Social Science, no. 5 (2009): 351; Paul Gill, John Horgan, and Paige Deckert, "Bombing Alone: Tracing the Motivations and Antecedent Behaviors of Lone-Actor Terrorists," Journal of Forensic Sciences 59, no. 2 (2014): 427; Steven Chermak and Jeffrey A. Gruenewald, "Laying a Foundation for the Criminological Examination of RightWing, Left-Wing, and Al Qaeda-Inspired Extremism in the United States," Terrorism and Political Violence 27, no. 1 (2015): 150.

${ }^{20}$ Jytte Klausen, Tyler Morrill, and Rosanne Libretti, “The Terrorist Age-Crime Curve: An Analysis of American Islamist Terrorist Offenders and Age-Specific Propensity for Participation in Violent and Nonviolent Incidents," Social Science Quarterly 97, no. 1 (2016): 19.

${ }^{21}$ Jonathan Rae, "Will it Ever be Possible to Profile the Terrorist?" Journal of Terrorism Research 3, no. 2 (2012): 64-74.

${ }^{22}$ Wike, Stokes, and Simmons, "Europeans Fear Wave of Refugees Will Mean More Terrorism, Fewer Jobs," 3.

${ }^{23}$ Randahl, "Refugees and Terrorism," 48.

${ }^{24}$ Evren Ceritoglu, H. Burcu Gurcihan Yunculer, Huzeyfe Torun, and Semih Tumen, “The Impact of Syrian Refugees on Natives' Labor Market Outcomes in Turkey: Evidence from a Quasi-Experimental Design," IZA Journal of Labor Policy 6, no. 5 (2017): 17.

${ }^{25}$ Semih Tumen, "The Economic Impact of Syrian Refugees on Host Countries: QuasiExperimental Evidence from Turkey," American Economic Review: Papers and Proceedings 106, no. 5 (2016): 458.

${ }^{26}$ Oğuz Esen and Ayla Oğuş Binatl1, "The Impact of Syrian Refugees on the Turkish Economy: Regional Labour Market Effects,” Social Sciences 6, no. 4 (2017): 129. 
${ }^{27}$ Ali Fakih and May Ibrahim, "The Impact of Syrian Refugees on the Labor Market in Neighboring Countries: Empirical Evidence from Jordan," Defence and Peace Economics 27, no. 1 (2016): 77.

${ }^{28}$ Amdadullah Baloch, Said Zamin Shah, Zaleha Mohd Noor, and Miloud Lacheheb, "The Economic Effect of Refugee Crises on Neighbouring Host Countries: Empirical Evidence from Pakistan," International Migration 55, no. 6 (2017): 90.

${ }^{29}$ J. Edward Taylor, Mateusz J. Filipski, Mohamad Alloush, Anubhab Gupta, Ruben Irvin Rojas Valdes, and Ernesto Gonzalez-Estrada, "Economic Impact of Refugees," Proceedings of the National Academy of Sciences of the United States of America 113, no. 27 (2016): 7450.

${ }^{30}$ Adrian-Ioan Damoc, "Fortress Europe Breached: Political and Economic Impact of the Recent Refugee Crisis on European States," Annals of the University of Oradea: Economic Science 25, no. 1 (2016): 21-22.

31،"Global Terrorism Database,” last modified July 2018, https://www.start.umd.edu/gtd/ (accessed March 1, 2018).

32،(GTD) Codebook: Inclusion Criteria and Variables," last modified July 2018, https://www.start.umd.edu/gtd/ (accessed March 1, 2018): 10.

${ }^{33}$ The 'persons of concern' group includes refugees, asylum-seekers, internally displaced persons (IDPs), returned refugees, returned IDPs, stateless persons, and "others of concern" - in every case, those who have been uprooted from their homes and have not as yet reestablished themselves there. "UNHCR Statistics: The World in Numbers," UNHCR.

34“"The World Bank: Data,” https://data.worldbank.org/indicator (accessed March 1, 2018).

${ }^{35}$ Monty G. Marshall, Ted Robert Gurr, and Keith Jaggers, "Polity ${ }^{\mathrm{TM}}$ IV Project: Political Regime Characteristics and Transitions, 1800-2017," Systemic Peace ([dataset]; accessed March 1, 2018), http://www.systemicpeace.org/polityproject.html.

${ }^{36}$ Monty G. Marshall, "Major Episodes of Political Violence (MEPV) and Conflict Regions, 1946-2016," Systemic Peace ([dataset]; accessed March 1, 2018), http://www.systemicpeace.org/inscrdata.html.

${ }^{37}$ Arch Puddington, Jennifer Dunham, Elen Aghekyan, Shannon O’Toole, Tyler Roylance, and Sarah Repucci, "Freedom in the World 2017: The Annual Survey of Political Rights and Civil Liberties," Freedom House ([dataset]; accessed March 1, 2018), https://freedomhouse.org/reporttypes/freedom-world.

${ }^{38}$ Alberto Abadie, "Poverty, Political Freedom, and the Roots of Terrorism," The American Economic Review 96, no. 2 (2006): 54. 
${ }^{39}$ Christopher W. Mullins and Joseph K. Young, "Cultures of Violence and Acts of Terror: Applying a Legitimation-Habituation Model to Terrorism," Crime \& Delinquency 58, no. 1 (2012): 28.

${ }^{40}$ Mark Gibney, Reed M. Wood, Linda Cornett, Peter Haschke, and Daniel Arnon, "The Political Terror Scale," Political Terror Scale ([dataset]; accessed March 1, 2018), http://www.politicalterrorscale.org/Data/Documentation.html.

${ }^{41}$ State violence includes things like torture, unlawful use of deadly force, extra-judicial executions, political imprisonment, arbitrary arrests, and kidnappings.

${ }^{42}$ Choi and Salehyan, "No Good Deed Goes Unpunished," 59.

${ }^{43}$ Ibid.

${ }^{44}$ Aldo M. Garay, Elizabeth M. Hashimoto, Edwin M. M. Ortega, and Victor H. Lachos, "On Estimation and Influence Diagnostics for Zero-Inflated Negative Binomial Regression Models," Computational Statistics and Data Analysis 55, no. 3 (2011): 1304.

${ }^{45}$ The count sides of the zero-inflated negative binomial models included the fixed effects variables; this was not possible for the zero sides of the models, because of issues of perfect collinearity.

${ }^{46}$ Including lagged dependent variables might run the risk of "soaking up" the explanatory power of other variables in the models (see Choi and Salehyan, "No Good Deed Goes Unpunished," 59). To check that this was not the case, the regressions were performed without including the lagged dependent variables. Removal of these variables did not change the (lack of) significance in either of the refugee variables, and, in fact, when the lagged dependent variable was removed from the second model, the variable for the number of displaced persons, previously significant at the 0.1 level, became non-significant.

${ }^{47}$ Abadie, "Poverty, Political Freedom, and the Roots of Terrorism," 54.

${ }^{48}$ Siobhan Kattago, "The End of the European Honeymoon? Refugees, Resentment and the Clash of Solidarities," Anthropological Journal of European Cultures 26, no. 1 (2017): 35-52; Michael Ignatieff, "The Refugee as Invasive Other," Social Science Research 84, no. 1 (2017): 225.

${ }^{49}$ Ignatieff, "The Refugee as Invasive Other,” 224-225.

${ }^{50}$ Ibid., 226.

${ }^{51}$ Maryellen Fullerton, "Trump, Turmoil, and Terrorism: The US Immigration and Refugee Ban,” International Journal of Refugee Law 29, no. 2 (2017): 332.

${ }^{52}$ Stern, “'Our Refugee Policy is Generous',” 35. 
${ }^{53}$ Kattago, "The End of the European Honeymoon?" 50; Ignatieff, "The Refugee as Invasive Other," 230-231. 